\title{
Various Aspects to Consider with Regard to Special Insolvency Rules for Small and Medium-Sized Enterprises in South Africa
}

\author{
André Boraine ${ }^{1}$, ${ }^{\dagger}$ and Jani van Wyk $k^{2,+}$ \\ ${ }^{1}$ Faculty of Law, University of Pretoria, Pretoria, South Africa \\ ${ }^{2}$ University of Pretoria, Pretoria, South Africa
}

\begin{abstract}
The notion of special insolvency rules for small and medium-sized enterprises (SMEs) has attracted attention in international spheres, and within the ambit of some international and comparative approaches, same is considered in this article with particular focus on the South African position. In particular, we show that the South African insolvency regime does not, at present, cater for financially distressed small businesses in a specific and viable manner. In South Africa, although attention has been paid to the development and support of small businesses, similar considerations have not been observed with regard to the insolvency side of small business concerns. No comprehensive and focused process of dealing with financially distressed small businesses exists in the South African insolvency framework. This scenario prevails, notwithstanding that there are existing foreign and international policy guidelines, rules and regimes in developed jurisdictions that can serve as pointers in this regard. The purpose of this article is to first highlight the need for special treatment of small businesses by focusing on the shortcomings in the South African system, and, as a natural sequential development, policy proposals as unavoidable foundations to address these shortcomings. In the premises, the focus is on the principles and policies that are relevant to any discussion regarding insolvent businesses that fall within the scope of the SME category. Therefore, this paper deals with the concept of the small business, the South African insolvency regime and the international position pertaining to small businesses. In particular,
\end{abstract}

\footnotetext{
*E-mail: Andre.Boraine@up.ac.za

†André Boraine is a Professor of Law, Dean of the Faculty of Law, University of Pretoria, South Africa [BIur LLB (Pret) LLM (Wits) LLD (Pret)]

+Jani van Wyk is a doctoral student under the auspices of the ABSA Chair in Banking Law in Africa,

University of Pretoria, South Africa [LLB, LLM (Pret)]
} 
the need for special treatment of SMEs under insolvent circumstances is discussed, consideration is given to the existing South African mechanisms available to small businesses in distress and the lack of suitable contextual provisions for small businesses in distress is noted. A core component of this article is the position in South Africa viewed against the backdrop of some international developments, international documents and principles that are relevant to an insolvency and rescue/rehabilitation regime within the context of the small business. As a logical conclusion, recommendations for reform of the South African regime are made. Copyright $\mathbb{C}$ 2015 INSOL International and John Wiley \& Sons, Ltd

\section{Part 1}

\section{Introduction}

The notion of special insolvency rules for small and medium-sized enterprises (SMEs) has attracted attention in international spheres and, within the ambit of some international and comparative approaches, same is considered in this article with particular focus on the South African position. In particular, we show that the South African insolvency regime does not, at present, cater for financially distressed small businesses in a specific and viable manner. This scenario prevails, notwithstanding that there are existing foreign and international policy guidelines, rules and regimes in developed jurisdictions that can serve as pointers in this regard. This paper is divided into three parts: the first deals with the concept of the small business, the second part with the South African insolvency regime and the third part with the international position pertaining to small businesses.

In general, the value of businesses that are diminutive in size, as opposed to larger corporation type of enterprises, has become notable for its economic contribution to a nation's prosperity and expansion. ${ }^{1}$ An assortment of reasons have been forwarded to support this statement of which two prominent beneficial aspects, from both public and private perspectives, are the creation of wealth through eco-

1. See e.g. Anneli Loubser 'Defining the unincorporated business in financial distress: Should it be treated as a business or as a consumer?' 2007 (19) SAMercL7 444, 448-449; Ronald Mann, 'The role of secured credit in small-business lending' 1997 (86) GeoLf 1, 4-5; Michael P Malloy 'Built to scale: Small business policy and the meltdown' 2012 Mich. St. L. Rev 7, 38; Organization for Economic Co-operation and Development, Small Businesses, Job Creation and Growth: Facts, Obstacles and Best Practices <http://www.oecd.org/cfe/smes/ 2090740.pdf $>$ inter alia pages 7-9 for an international perspective and the Banking Association of South Africa, 'Small and Medium Enterprise' $<$ http://www.banking.org.za/index.php/our-industry/ small-medium-enterprise/ $>$ and the Department of Trade and Industry, 'Small Medium Micro Enterprise Development' <http://www.thedti.gov.za/ sme_development/sme_development.jsp $>$ for a domestic perspective (sites last accessed 6 and 7 January 2014).

2. See e.g. Organization for Economic Co-operation and Development (n 2) for an international perspective and the Banking Association of South Africa 'Small and Medium Enterprise' (n 2) and the Department of Trade and Industry 'Small Medium Micro Enterprise Development' (n 2) for a domestic perspective. See also JJ Henning and JT Pretorius (with specialist contributors A du Plessis, JA Henning, PS Brits and $\mathrm{JH}$ vd V Nel) Close Corporations and Companies Service Volume 1 (last updated September 2014 service issue 43) LexisNexis: Durban; electronic version available at $<$ http://0-www.mylexisnexis.co.za. innopac.up.ac.za/Index.aspx $>$ (site last accessed 8 April 2015) pages 1-7, 1-9 and 1-11. 
nomic stimulation and the creation of employment opportunities. ${ }^{2}$ Small businesses further have the latent potential to expand into larger businesses, ${ }^{3}$ plausibly with the resultant increased ability to congregate and distribute wealth. ${ }^{4}$

Developed nations, such as the USA, Japan and Hungary, have recognised the potential of small businesses to inter alia compete in segments of the commercial arena generated by larger firms or to 'outperform' larger business. ${ }^{5}$ Small businesses are feasible options for respectively contributing to the country's gross domestic product and for driving the economy. ${ }^{6}$ In the premises, various states have set mechanisms in motion in order to initiate, encourage and improve on the development and preservation of small-sized enterprises. ${ }^{7}$ In addition, a change in the approach to failing businesses in general, thus whether large or small, from liquidation to rehabilitation, has been observed in both the domestic and in foreign jurisdictions. ${ }^{8}$

The Republic of South Africa is no exception when it comes to preferential attention assigned to small businesses in order to derive national economic

3. Peter Pandelani Nemaenzhe, Retrospective analysis of failure causes in South African small businesses. $\mathrm{PhD}$ Thesis, (University of Pretoria), September $2010<$ http://upetd. up.ac.za/thesis/available/etd-10142011-180611/> (site last accessed 9 January 2014) chapter 1 page 3. See also Report commissioned by the National Credit Regulator compiled by Underhill Corporate Solutions, 'Literature Review on Small and Medium Enterprises Access to Credit and Support in South Africa' < http://www.ncr.org.za/pdfs/Research_Reports/Literature $\% 20$ Review $\% 20$ on $\% 20$ SME $\%$ 20 Access $\% 20$ to $\% 20$ Credit $\% 20$ in $\% 20$ South $\% 20$ Africa Final\%20Report_NCR_Dec\%202011.pdf> (site last accessed 28 February 2014) page 13; See also Pieter Kloppers, 'Judicial management - a corporate rescue mechanism in need of reform?' 1999 10(3) Stell LR 417, 425.

4. See the comments of David Mmakola, 'South Africa's SMME policy - the challenge remains' 2009 39(2) Africanus 66, 71, in respect of growth and sustainable employment. The author argues at 71 that it is not enough merely to support small businesses but that the resources invested should be focused on true business endeavours that have the ability to expand. He notes at 71 that mere attention to small businesses is not adequate in respect of employment creation as it is first uncertain whether the potential for employment opportunities is due to the size and 'labour intensi[ty]' of the business or merely 'sector' related - he refers specifically to the clothing and furniture sectors. Secondly, he notes at 71 that not all small businesses are entrepreneurial in nature in the sense that many businesses may simply be transitory as a result of the current state of unemployment in South Africa and therefore exist only until the owner-manager obtains suitable employment. See also SBP Alert 'Developing a new path for SMEs in South Africa', Issue Paper 12013 <http://www.sbp.org. za/uploads/media/SBP_Alert___Developing_a_new_path for_SMEs_in_South_Africa.pdf $>$ (site last accessed 2 July 2014), e.g. page 3.

5. Nemaenzhe (n 3) chapter 1 page 8.

6. Idem at pages 7 and 10; Klopper (n 3) 417, 425. See also Underhill Corporate Solutions (n 3) page 13 and RC Beuthin and SM Luiz, Beuthin's Basic Company Law $3^{\text {rd }}$ edn (updated to August 1999) <http://0-www. mylexisnexis.co.za.innopac.up.ac.za/Index.aspx $>$ (site last accessed 8 April 2015) chapter 33 pages 303-304.

7. See also the brief comparative compilation on the economic contribution of small and medium-sized enterprises in the USA, Japan, Britain, Denmark, Hungary, Sweden, Africa and South Africa by Nemaenzhe (n 3 ) chapter 1 pages $7-11$.

8. Denine Smit and Veruschka Vergottini 'Die invloed van 'n werkgewer se likwidasie en/of boedelsekwestrasie op die diensverhouding met die werknemer, met die oog op ondernemingsredding as moontlike alternatief 2013 (10) LitNet Akademies 83, 93-94. This does not relate solely to small businesses - see Andrew Godwin, 'Corporate rescue in Asia - trends and challenges' 2012 (34) Sydney L. Rev. 163, 163 et seq; Chinwe Chiwete, An examination of insolvency alternatives for corporate and non-corporate entities in South Africa, LLM dissertation (University of Pretoria) October $2011<\mathrm{http} / / /$ upetd.up.ac.za/thesis/available/etd-09132012-185858/ $>$ (site last accessed 23 June 2014) chapter 1 page 3.

9. The Department of Trade and Industry, 'Small Medium Micro Enterprise Development' <http://www. thedti.gov.za/sme_development/sme_development.jsp > (site last accessed 6 January 2014) - see the Department of Trade and Industry, 'Legislation and Business Regulation' $<$ http://www.thedti.gov.za/business_regulation/legislation.jsp $>$ (site last accessed 9 April 2014). 'More ways to secure working capital' < http://www.fin24.com/Entrepreneurs/Getting-Started/More-ways-to-secure-workingcapital-20140624> (Fin24, 24 June 2014, site last accessed 28 June 2014). There is also the view that South Africa has not performed adequately with regard to small businesses - see 'SMEs vital for jobs and growth, Zuma told' <http://www.fin24.com/Entrepreneurs/News/SMEsvital-for-growth-and-jobs-Zuma-told-20140617> (Fin24, 17 June 2014, site last accessed 28 June 2014); See also Harry Rajak and Johan Henning, 'Business rescue for South Africa' 1999 (116) SAL7 262, 269; In respect of a 'form' for a small business, see Henning and Pretorius (n 2), e.g. 1-3, 1-7, 1-9 and Beuthin and Luiz (n 6) chapter 33 pages 303-304. 
benefits from the activities of these businesses. ${ }^{9}$ The government recently established a Ministry for Small Business tasked with the advancement of small enterprises $^{10}$ and allocated R6.5 billion in the 2014 budget speech towards assisting small and medium-sized businesses over the subsequent three year period. ${ }^{11}$ This is not an unexpected development as the presence of small, medium and micro-enterprises in South Africa is notable. A survey conducted by the FinMark Trust titled the Finscope Small Business Survey provides some statistical information regarding small businesses, which were surveyed as such where the business owner was older than 16 years and less than 200 employees were involved in the business. ${ }^{12}$ The survey indicated the presence of approximately six million small businesses in South Africa of which these businesses are the only source of income for $67 \%$ of the approximated five and a half million small business owners. ${ }^{13}$ Furthermore, 33\% of these owners employ other persons - in respect of the $67 \%$ of the remaining businesses, the owner is the only person working in the business. ${ }^{14}$ Seventeen percent have registered their businesses. ${ }^{15}$ Seventy nine percent trade in goods, of which nearly $50 \%$ trade these goods without adding value (buy and sell as is) ${ }^{16}$ and $6.5 \%$ trade in products that they, as owners, have grown, bred, produced (such as animal by-products) or gathered from nature. ${ }^{17}$ Professional occupations account for a mere $5 \%$ of small businesses and $21 \%$ of the small businesses generate income through the provision of services. ${ }^{18}$

Unfortunately, business failure is as much a reality for small businesses as it is for large businesses with its own repercussions. ${ }^{19}$ The impact that the

10. 'New ministry for small business' < http://www. fin24.com/Entrepreneurs/News/New-ministry-for-smallbusiness-20140525> (25 May 2014, Fin24, site last accessed 22 June 2014); 'SMEs vital for jobs and growth, Zuma told' (n 9).

11. 2014 Budget Speech by Minister of Finance Pravin Gordhan 26 February 2014 page $17<$ http://www. treasury.gov.za/documents/national\%20budget/2014/ speech/speech.pdf> (site last accessed 8 April 2015); 'First identify challenges to small business: Zulu' $<$ http://www.southafrica.info/business/economy/smallbusiness-260514.htm\#.U6lhfPmSzIY> (South Africa. info, 27 May 2014, site last accessed 24 June 2014). At the time of the budget speech, the US Dollar-RSA Rand exchange rate was 1 USD: 10.8448 ZAR - see <http://www.exchangerates.org.uk/USD-ZAR-26 02 2014-exchange-rate-history.html $>$ (site last accessed $1 \overline{5}$ April 2015). In a similar fashion, the Western Cape Province has allocated R179 million to small and medium-sized enterprise development 'R179 million for small firms in the Cape' < http://www.fin24.com/Entrepreneurs/News/R179m-for-small-firms-in-the-Cape20140620> (Fin 24, 20 June 2014, site last accessed 28 June 2014).

12. FinMark Trust < http://www.finscope.co.za/finscope/ pages/Initiatives/Small-Business.aspx? randomID=b6af 2bb2-5289-4efc-9b14-3f8145241714\&linkPath=3\&lID= 3_3 > (site last accessed 1 April 2014). Report of 2010 'The FinScope South Africa Small Business Survey' available from <http://www.finscope.co.za/finscope/pages/ Initiatives $/$ Small-Business.aspx?randomID $=\mathrm{b} 6 \mathrm{af} 2 \mathrm{bb} 2$ 5289-4efc-9b14-3f8145241714\&linkPath=3\&lID =3 3> 13. FinMark Trust (n 12). The sample size for the study was 5676 small businesses.

14. Ibid.

15. FinMark Trust (n 12) and FinMark Trust Finscope Report (n 12) page 2.

16. FinMark Trust (n 12).

17. FinMark Trust Finscope Report (n 12) page 2.

18. Ibid. See Henning and Pretorius (n 2) pages 1-3 in respect of the number of close corporations registered and active, compared with companies. The author's point of departure, as can be ascertained from the discussions on e.g. pages $1-3,1-7,1-9$, $1-11,1-35$ and $1-37$, is that close corporations are well suited to small business endeavours.

19. Kanitsorn Terdpaopong and Omar Al Farooque, 'Financial distress, restructuring and turnaround: evidence from Thai SMEs' 2012 (2) RfAS 119, 119-120 \& 128. See also Statistics South Africa Statistics of Liquidations and Insolvencies (Preliminary) February 2014 Statistical Release P0043 at 2, 3 and 9, available at <http://beta2.statssa.gov.za/?page id $=1854 \& \mathrm{PPN}=$ $\mathrm{P} 0043 \& \mathrm{SCH}=5782>$ (site last accessed 2 July 2014) in respect of the number of liquidations in South Africa for the stated period. Note that reference is not made to the size of the enterprise in the official publication of the statistics. 
insolvency of a debtor versus that of a business has on other stakeholders such as dependants, employees, financiers, other traders and 'the wider community in which [the business] operates' is a relevant consideration that directly relates to the issue of dealing with a particular type of debtor in insolvency. ${ }^{20}$ In cases where the business is the only income for the owner including cases where the owner is the only person working in the business, business failure can also have a profound effect on the personal financial circumstances of the individual. ${ }^{21}$

The failure of a business has severe economic consequences and substantial costs, both financial and psychological, to numerous parties involved. The economic cost of business failures [is] significant in terms of both direct and indirect effects that include among others the expenses of either liquidating or attempting to restructure the internal financial domain of the business, accounting and legal fees and other professional service costs that resulted due to the crisis. ${ }^{22}$

Review of the South Africa insolvency law has been an on-going process for numerous years. ${ }^{23}$ As early as 1987, the South African Law Commission commenced an investigation of the law of insolvency in its entirety, and a Project Committee was appointed to conduct and direct the review as Project 63. A series of working papers for discussion dealing with selected topics, followed by reports, ${ }^{24}$ culminated in the Draft Insolvency Bill of $1996 .{ }^{25}$ This first draft was replaced by the Report and Draft Bill that was published by the South African Law Reform Commission during 2000. ${ }^{26}$ In 2003, the Cabinet approved a consolidated version of the insolvency legislation, embodied in the Unified Insolvency Act, that would apply to various types of debtors, in effect, namely natural person debtors (individuals), corporate and other entities. At present, apart from a Working Document of the Department of Justice dated 30 June 2010 and later informal versions dated 2013 and 2015, respectively, a formal Reform Bill has not yet been published.

The first Draft Insolvency Bill was published for comment in 1996 even though research on certain important issues had not been finalized at that time. For

20. See Loubser 'Defining the unincorporated business' (n 1) 444, 444-445 and Muir Hunter, 'The Nature and functions of a rescue culture' 1999 J. B. L. 491, 497-498.

21. See also paragraph 1 in respect of the Finscope Survey.

22. Terdpaopong and Farooque (n 19) 119, 120.

23. Prior to 1987 some ad hoc working documents like the South African Law Commission Preferences on Insolvency Project 37 Working Paper 11982 and its subsequent Report on the Review of Preferent Claims in Insolvency Project 37 Interim Report 1984 were published.

24. In contrast with the position in the USA and England, the Project Committee did not compile a full report regarding the investigation.
25. The 1996 Draft Insolvency Bill and Explanatory Memorandum were published for comment by the South African Law Commission as the Review of the Law of Insolvency: Draft Insolvency Bill and Explanatory Memorandum Working Paper 66 Project 63 1996. See further André Boraine and Kathleen van der Linde 'The Draft Insolvency Bill - An Exploration' (Part 1) 1998 (4) TSAR 621 and 'The Draft Insolvency Bill - An Exploration' (Part 2) 1999 (1) TSAR 38.

26. André Boraine and Melanie Roestoff, 'Revisiting the state of consumer insolvency in South Africa after twenty years: The courts' approach, international guidelines and an appeal for urgent law reform (2)' 2014 (77) THRHR 527, 527. 
example, cross-border insolvencies and the issue of unifying the insolvency provisions for individuals and juristic persons like companies and close corporations were not dealt with in that Bill. ${ }^{27}$ The later version, the 2000 Draft Bill, also did not include corporate insolvency law provisions but, as mentioned in the previous paragraph, Cabinet gave the go-ahead for a Unified Insolvency Act in 2003. ${ }^{28}$ This version has not been formally published. The aforementioned working document dated 30 June 2010 contains a draft of a possible unified bill, at present titled the Draft Insolvency and Business Recovery Bill, ${ }^{29}$ but it is not yet officially in the public domain. The latest version is the 2015 version, but reference will also be made to the 2003 draft as this version was made publicly available via the relevant Government Department's website.

Meanwhile the Department of Trade and Industry embarked on a process to reform the company laws of South Africa and the new Companies Act 71 of 2008 became operational on 1 May 2011. Item 9 of Schedule 5 of the 2008 Companies Act mentions the introduction of new insolvency legislation that will probably also deal with the winding-up of insolvent companies.

\section{Orientation}

Notwithstanding the abovementioned benefits associated with a healthy small business environment, the small business is a commercial occurrence that is not without its challenges when it comes to developing legal frameworks for its regulation. ${ }^{30}$ Difficulties are observed from initiation to dissolution of these businesses as criticism levied against regulatory intervention range from resource consuming 'red tape' to lack of proper legislative provisions, including

27. The term 'debtor' is not defined as it is not settled if companies and other legal persons should be included in a new Act. This issue is not as simple as finding an appropriate definition though, as the application of every clause of the 1996 Draft Insolvency Bill with regard to the various types of debtors will have to be considered. See Boraine and Van der Linde 'Part 1' (n 25) 621, 621 and Boraine and Van der Linde 'Part 2' (n 25) 38,38 et seq.

28. Boraine and Roestoff 'Part 2' (n 26) 527, 527 also state that '[i]n March 2003, cabinet accepted the concept of a new unified Insolvency Act dealing with the liquidation of both natural person and business debtors, but this initiative has stalled'.

29. Boraine and Roestoff 'Part 2' (n 26) 527, 527.

30. See e.g. the focus points determined by the UNCITRAL working group United Nations Commission on International Trade Law Forty-sixth session, Vienna, 8-26 July 2013 <http://daccess-dds-ny.un. org/doc/UNDOC/GEN/V13/832/76/PDF/

V1383276.pdf?OpenElement $>$ (site last accessed 23 June 2014). These range from inception to dissolution of small and medium-sized enterprises. See Henning and Pretorius (n 2) pages $1-3-1-11$ and $1-25,1-29$, $1-35$ and $1-37$ in respect of the close corporation as an option for the embodiment of a small business as well as the criticism against general uniform company (and rescue) legislation application to close corporations and companies irrespective of size, e.g. page $1-37$ : ' [] $\mathrm{t}$ is very difficult, if not impossible, for a single Act to provide a satisfactory legal form for both the large and sophisticated as well as the small and often marginalised entrepreneur'. See also similar commentary in Beuthin and Luiz (n 6) chapter 33 pages 303-304. See Johan J Henning, 'The impact of South African company law reform on close corporations: Selected issues and perspectives' 2010 Acta Furidica 456 for a discussion of the envisaged changes to the company law framework in South Africa as well as commentary on the close corporation as medium for a small business. However, the statement of Henning and Pretorius (n 2) referred to above is made in general terms, and the authors view the applicability of the business rescue procedure to close corporations in a favourable light - see page 1-29. Business rescue proceedings are discussed in paragraph 3.1.4.4 infra. 
provisions in respect of distressed businesses. ${ }^{31}$ Apart from the multiple developments in respect of failing businesses in general, dealing with small businesses in distress has been the focus of writers of foreign jurisdictions and international organisations. $^{32}$ In South Africa, although attention has been paid to the development and support of small businesses, ${ }^{33}$ similar considerations have not been observed with regard to the insolvency side of small business concerns. No comprehensive and focused process for dealing with financially distressed small businesses exists in the South African insolvency framework.

This paper is concerned with the last criticism levied at the Legislator. We argue the need for special treatment of SMEs under insolvent circumstances. First, we briefly deliberate on whether South Africa needs special insolvency rules for SMEs and, if so, the reasons therefore. As a basis for the deliberation, we deal with the South African mechanisms available to small businesses in distress and criticise the lack of suitable contextual provisions for small businesses when in distress. It will, for example, be illustrated that in spite of the introduction of a new business rescue procedure in the Companies Act of 2008, due consideration should still be given to special rules for the treatment of insolvency issues relating to SMEs. This aspect should also be considered within the ambit of the broader South African insolvency law reform project that is currently underway as mentioned in the previous paragraph.

In addition we briefly mention international documents and principles that are valuable to consider with regard to an insolvency and rescue/rehabilitation regime within the context of the small business. We refer specifically to the Asian Development Bank Informal Workout Principles and the European Commission Commission Recommendation of 12.3.2014 on a new approach to business failure and insolvency

31. See e.g. Chris Barron, 'Red Tape stifles small businesses' <http://www.bdlive.co.za/businesstimes/ 2013/03/03/red-tape-stifles-small-businesses> (Business Times BDLive, 3 May 2013, site last accessed 20 January 2014); Linda Ensor, 'South African labour laws "flexible enough" (BD Live (national/labour), 24 June 2013) <http://www.bdlive.co.za/national/labour/2013/06/24/south-african-labour-laws-flexibleenough $>$ and Linda Ensor 'Business cries foul over labour law changes' (BD Live (national/labour), 20 September 2013) <http:// www.bdlive.co.za/national/labour/2013/09/18/business-cries-foul-overlabour-law-changes $>$ (sites last accessed 7 March 2014 (labour laws)); Natasha Marrian 'Small business minister will not start big job from scratch' < http://www. bdlive.co.za/business/2014/06/25/small-business-minister-will-not-start-big-job-from-scratch> ( BD Live, 25 June 2014, site last accessed 2 July 2014); Department of Trade and Industry (author: Rae Wolpe) Guidelines for reducing municipal red tape-How municipalities can improve service delivery that supports small business 2013 (ISBN: 978-0-621-41266-6); Henning and Pretorius (n 2) pages $1-7,1-25,1-35$ and $1-37$, e.g. in respect of the general 'complex[ity]' of legislation pertaining to companies, including 'the small private company', Loubser 'Defining the unincorporated business' (n 1) 444, 449; Kloppers (n 3) 417, 424-425 - the latter in respect of the applicability of the repealed procedure of judicial management with regard to 'small private companies'.

32. See e.g. Edward Morrison, 'Bargaining around bankruptcy: Small business workouts and state law' 2009 (38) 7. Legal Stud. 255; Gerard McCormack, 'Rescuing small businesses: Designing an "efficient" legal regime' 2009 7. B. L. 299; UNCITRAL Legislative Guide on Insolvency Law (2004), e.g. page 284; UNCITRAL Forty-sixth session (n 30) pages 15-17 $\& 20$.

33. See e.g. Department of Trade and Industry, 'Small Medium Micro Enterprise Development,' (n 2); Fin24 (n 9); Ebrahim-Khalil Hassen, 'Can South Africa's new Small Business development Ministry promote structural change?' < http://www.polity.org.za/article/ can-south-africas-new-small-business-developmentministry-promote-structural-change-2014-05-29> (Polity.org.za, 29 May 2014, site last accessed 24 June 2014). 
(Brussels). This approach does not serve to express an opinion that the work of other organisations such as UNCITRAL and INSOL is not important; however, the latter two organisations' inputs have been the subject of some discussion by South African authors as shown below. In addition, the EU Commission Commission Staff Working Document Impact Assessment Accompanying the document Commission Recommendation on a New Approach to Business Failure and Insolvency refers to these organisations. Selected relevant mechanisms, both national and international, that are available to work with in creating special insolvency rules are duly noted and reference made to the foreign jurisdictions of Japan and South Korea to illustrate our recommendation of legislative intervention.

In light of the complexity and multiplicity of aspects surrounding businesses, it is also important to demarcate the scope of the discussion. An in-depth analyses and discussion of each aspect and shortcoming within a particular legal structure such as business rescue, for example, is beyond the scope of the discussion. The discussion would then by necessity have to include an analysis of the whole branches of South African law. The purpose of this article is to first highlight the need for special treatment of small businesses by focusing on the shortcomings in the current South African framework and, as a natural sequential development, policy proposals as unavoidable foundations to address these shortcomings. In the premises, the focus is on the principles and policies that are relevant to any discussion regarding insolvent businesses that fall within the scope of the SME category. Selected core issues, based on shortcomings in the South African system, are discussed, and in conclusion, some suggestions are made for reform within the South African legal system. Therefore, the references made to some existing analyses by authors relate to individual aspects for further reading whilst the discussion will only incorporate those aspects directly relevant to addressing the issues set out above.

As a general point of departure and international guideline for adaptation by the South African insolvency regime, therefore the following extract:

Finally, the Commission may wish to address the insolvency of MSMEs with the objective to ensure fast-track procedures and business rescue options so as to develop adequate and workable alternatives to formal insolvency processes in line with both the key characteristics of an effective insolvency system and the needs of MSMEs. Guidance could focus, inter alia, on matters such as use of informal procedures; commencement of proceedings, including expedited proceedings; applicable remedies, e.g. reorganization or liquidation; treatment of assets; and the administrative structure of the insolvency regime. Guidelines already developed by international organizations, such as UNCITRAL's Legislative Guide on Insolvency Law (2004) and INSOL's Statement of Principles for a Global Approach to Multi-Greditor Workouts, can serve as building blocks for this work. ${ }^{34}$

34. UNCITRAL Forty-sixth session (n 30) page 20.

References omitted. 


\section{The Framework for Special Insolvency Rules}

The value of a suitable insolvency system should not be underestimated within the context of economic growth and business development:

A robust bankruptcy system functions as a filter, ensuring the survival of economically efficient companies and reallocating the resources of inefficient ones. Fast and cheap insolvency proceedings result in the speedy return of businesses to normal operation and increase returns to creditors. By improving the expectations of creditors and debtors about the outcome of insolvency proceedings, well-functioning insolvency systems can facilitate access to finance, save more viable businesses and thereby improve growth and sustainability in the economy overall. ${ }^{35}$

In a similar fashion, it is of importance to develop alternatives as options for debtors in distress ${ }^{36}$ particularly when considering the divergent features that may vary the facts and circumstances of each debtor in distress. ${ }^{37}$ Ultimately, any procedure developed or amended in order to address the needs of enterprises in financial difficulty needs to be beneficial on some distinguishable level (from other enterprises and/or other debtors and/or other procedures ${ }^{38}$ ) in proposing either liquidation or rehabilitation measures for SMEs. Much has been written about rehabilitation and reconstruction of corporate debtors in financial distress and, in a similar fashion, the natural person (mostly consumer) debtor, ${ }^{39}$ as can be seen from the various sources referred to throughout this paper. The primary distinguishing characteristic of the SME for purposes of this discussion, apart from size, is a uniquely present owner-manager-worker relationship ${ }^{40}$ and the opportunities and practices that manifest as a result thereof. Examples

35. World Bank Doing Business 2014: Understanding Regulations for Small and Medium-Size Enterprises. Washington, DC: World Bank Group (country profile: South Africa) 2013 (DOI: 10.1596/978-0-8213-96155), <http://doingbusiness.org/reports/global-reports/ $\sim /$ media/giawb/doing\%20business/documents/profiles/country/ZAF.pdf $>$ (site last accessed 8 January 2014) page 92. See also UNCITRAL Forty-sixth session (n 30) page 15.

36. Chiwete (n 8) page ii and chapter 1 page 3; UNCITRAL Forty-sixth session (n 30) page 20. Some statements in the European Commission Commission Recommendation of 12.3.2014 on a new approach to business failure and insolvency (Brussels 2014) inter alia page 2 paragraph 2 show that restricted options, whether in number or in substance (such as the stage when restructuring is allowable or the efficiency of non-judicial processes vis-à-vis court processes) can obstruct the achievement of the ultimate goal of dealing with failing business in a constructive manner.

37. André Boraine, 'Some thoughts on the reform of administration orders and related issues,' 2003 (36) De fure 217, 235-236. The EC Recommendation (n 36) page 4 paragraph 17 and page 6 paragraph III B 9 advocate a 'case-by-case' approach when deciding aspects such as whether to involve third-party dispute resolution agents or overseers. In respect of the unique needs of small businesses, see UNCITRAL Forty-sixth session (n 30) page 16. 38. See Loubser 'Defining the unincorporated business' (n 1) 444, 444 et seq and e.g. at 444 and 449

39. Boraine (n 37) 217, 238: '[A] debtor whose liabilities are incurred primarily for private, family or household purposes and not, in the first place, as a result of carrying on business, or the granting of guarantees for other persons' debt'. See further Loubser 'Defining the unincorporated business' (n 1) 444,444 where the author refers to jurisdictions in which a distinction is made either based on the nature of the debtor (i.e. natural or juristic person) or based on the nature of the person's 'activities or sources of income' (i.e. consumer or trader). See also the comments of Klopper (n 3) 417, 418 in respect of the dissolution of the division between 'incorporated and unincorporated businesses' in favour of a differentiation based on 'business' versus 'consumer'.

40. Morrison (n 32) 255, 256; McCormack (n 32) 299, 318. See also Heidi Schoeman 'Business Entities' in Heidi Schoeman (ed) An introduction to South African banking and credit law $2^{\text {nd }}$ ed 2013 LexisNexis: South Africa pages 97-98. 
of these practices include the strategic use of personal sureties for business debts as the impetus for responsible business management as irresponsible management may be correlated with the adverse effects of failure on the owner-manager's own estate. ${ }^{41}$

As a point of departure, some (problematic) characteristics of SMEs are discussed, whereafter the South African regulatory structure in respect of the insolvency regime is briefly summarised in order to highlight the shortcomings thereof in respect of small business insolvency.

\section{A. Specific aspects pertaining to small businesses in financial distress}

\section{(1) Business failure}

Any consideration of the value of SMEs, the need for assistance with development and preservation of these enterprises necessitates a brief reflection on the question of dealing with failing businesses. ${ }^{42}$ As will be seen throughout the discussion, a primary consideration by authors and organisations alike for the development and implementation of alternatives to deal with failing businesses is the viability of the business. First, the business motivation of the owner-manager is relevant as the following comment by Mmakola indicates:

...South Africa's SMMEs policy suffered from a failure to distinguish between those aspects of providing support to SMMEs that are the appropriate subject of an industrial policy, as opposed to support akin to a welfare policy. Put differently, not all people that have small businesses are entrepreneurs, emphasising the need for the proper categorisation of appropriate support for each one of them. In other words, there are people who end up being in business due to factors such as inability to secure paid employment. Such people are not necessarily entrepreneurs and are likely to leave their businesses as soon as job opportunities become available. There is a need to categorise business owners so that limited financial and other support to SMMEs can go to business owners that are truly entrepreneurs, as part of industrial policy. The remaining category of business owners can then be the focus of welfare policy. As a result of this confusion, considerable effort and resources have gone into attempts to improve management and access to finance for enterprises that have no realistic prospects of graduating into productive concerns. ${ }^{43}$

41. Mann (n 1) 1, 10 \& 19.

42. Terdpaopong and Farooque (n 19) 119, 120-121. See also Department of Trade and Industry South Africa Credit Law Review August 2003 Summary of the Findings of the Technical Committee available at < http:/ / www.ncr.org.za/publications/Background_NCA_docs/ Summary $\% 20$ of $\% 20$ Findings.pdf $>$ (site last accessed 2
June 2014) page 5: 'Serious weaknesses in insolvency law and certain sections of the Magistrates' Court Act (as relating to debt collection and enforcement against security) undermine housing and SME finance'.

43. Mmakola (n 4) 66, 71. References omitted. 
In a similar fashion, the European Commission's Recommendation approaches SME distress with the understanding that these businesses are in need of assistance 'to restructure and re-launch'. ${ }^{44}$ The Recommendation is generally aimed $^{45}$ at facilitating the utilisation of rearrangement methods by economically feasible enterprises experiencing pecuniary difficulties in order to restore the enterprises to financial health and with the ability to continue as a business concern. ${ }^{46}$ This includes a 'second-chance' approach for 'honest entrepreneurs'. ${ }^{47}$ The Recommendation further indicates that there is an increased probability of success for a debtor that attempts to construct another business after insolvency. ${ }^{48}$

Apart from the distinction between the 'serious' and 'temporary' entrepreneur, as can be ascertained from Mmakola's comment above, the reason(s) for the failure of a business is also a prominent consideration when contemplating the choice of mechanism to deal with a failing or failed business. ${ }^{49}$ This is a fundamental consideration when deliberating whether to liquidate the enterprise or attempt to salvage a business. ${ }^{50}$ Management dysfunction is a prime example of the relevance of the cause of failure to assess and choose the most favourable option for dealing with the distressed business. ${ }^{51}$ Comprehending the causes for failure relating to management dysfunction such as lack of training, competency or fraudulent behaviour ${ }^{52}$ is important when deciding on detailed courses of action,

44. EG Recommendation (n 36) page 3 paragraph 9. 45. The EC Recommendation (n 36) refers to small and medium-sized enterprises, but the document is not solely focused on these businesses. For further excluded entities, see page 4 paragraph 15.

46. EG Recommendation (n 36) inter alia page 2 paragraph 1 and page 5 paragraph I 1 .

47. Idem at page 5 paragraph I 1 .

48. Idem at page 5 paragraph 20.

49. Nemaenzhe (n 3) chapter 1 page 5. Morrison (n 32) 255,256 notes the obvious as a point of departure for his discussion as to the procedure preferred by small businesses and the reasons therefore. He indicates at 256 that business dissolution is not always due to pecuniary challenges, rendering bankruptcy deliberations irrelevant for these enterprises. In a similar fashion, the EC Recommendation (n 36) page 4 paragraph 16 states that a requirement to avert abuse of the restructuring process is needed, and the logical conclusion of the pecuniary distress, which is the rationale for the restructuring scheme, should be bankruptcy. The latter should be the focus of the scheme, which the rearrangement scheme would not only avoid but also cause the continuation of the enterprise as a successful concern - see page 4 paragraph 16.

50. See e.g. David Burdette, 'Some initial thoughts on the development of a modern and effective business rescue model for South Africa (Part 1)' 2004 (16) SAMercLf 241, 257 where the author refers to the primary aspects of the then-prevailing version of the UNCITRAL Draft Legislative Guide on Insolvency Law in respect of business rescue considerations that certain businesses deserve a further opportunity to prevail over pecuniary difficulties and resume at least the business of the enterprise, whether in the original or an amended version.

51. See e.g. Naoko Okamoto, 'Japan's business revitalization ADR: An economic savior or a convenient excuse to avoid bankruptcy' 2010-2011 (12) Cardozo 7. of Conflict Resolution 637, 660. In the context of the viability of mediation within the context of financial distress resolution, the author at 660 implores mediators to ascertain the framework within which financial distress occurs. The two references to 'a sudden change in economic climate' and 'fundamental flaws in running the business as a result of bad management' are used as contrasting circumstances under which mediation is, in the first instance, seen as a viable option by the author and in the second instance as 'only prolonging the life of a zombie company' (see 660); Rajak and Henning (n 9) 262, 279. The EC Recommendation (n 36) inter alia page 2 paragraph 4 and page 5 paragraph I 1 refers to the 'honest entrepreneur'.

52. Nemaenzhe (n 3) chapter 1 pages 5-6. See also Rajak and Henning (n 9) 262, 279 and the EC Recommendation (n 36) pages 9-10 paragraph IV 32. The latter, which deals with discharges, account for the behaviour of debtors, whether in the pre- or post insolvency procedure period. 
for example, whether to support a regime of management displacement vis-à-vis debtor-in-possession for a particular scenario of business failure. ${ }^{53}$

In respect of the debtor-owner-manager relationship, categorisation ${ }^{54}$ of the enterprise, conduct and perception of the owner becomes applicable. The implication of considering the aforementioned is briefly illustrated by way of reference to statements by Nemaenzhe, Burdette, Rajak and Henning. Nemaenzhe notes at the commencement of a study into the reasons for small business failure that the perception of the owner-manager in respect of the prospects of business success when difficulties arise is a relevant consideration. ${ }^{55}$ Burdette notes the cardinal importance for small business owners to attempt to obtain assistance at an early stage of business distress. ${ }^{56}$ Furthermore, the underlying policy framework and stakeholder mind-set that are focused on rehabilitation (whether this refers to retaining the business in a varied form or retaining the businesses value through sale as a going concern) ${ }^{57}$ or greater return for creditors without resorting to liquidation is more readily advanced in a debtor-friendly system. ${ }^{58}$ However, Rajak and Henning further consider, within the context of the 'development of a rescue culture', that certain debtors whose conduct are found to be implicated in the ultimate insolvency of the business may be restricted from

53. Nemaenzhe (n 3) chapter 1 pages 5-6. See also Rajak and Henning (n 9) 262, 282-285 and Godwin (n 8) 163, 167 and 178. The latter author at 167 refers to this form of management as beneficial within the scope of rescue proceedings initiated in respect of 'the family-controlled small and medium enterprises ... that are common in Asia'. In respect of the basic construction of a 'small business reorganisation regime', McCormack (n 32) 299, 330 is of the opinion that the 'debtor in possession with light touch monitoring of management' is an agreeable option. The author further notes at 330 that engagement with the judiciary will only be necessary where there is prejudice involved or severe irregularities with respect to the process. He points out that credit involvement in such a regime would be in respect of the endorsement of a restructuring plan - see 330. In respect of court involvement, David Burdette 'Some initial thoughts on the development of a modern and effective business rescue model for South Africa (Part 2)' 2004 (16) SAMercLf 409, 410 points to the challenges in respect of court involvement, namely time, cost and professional capacity. However, the only exceptions where formal insolvency and debt restructuring mechanisms under South African law do not include a non-negotiable element of court intervention are initiation of business rescue and company liquidation by resolution. However, where any process is opposed, the court will in all probability become involved (see paragraph 3.1.2 below). See also Boraine and Roestoff 'Part 2' (n 26) $527,534-536$ for the reference to court involvement in their overarching discussion of the World Bank Report (see André Boraine and Melanie Roestoff, 'Revisiting the state of consumer insolvency in South Africa after twenty years: The courts' approach, international guidelines and an appeal for urgent law reform (1)' 2014 (77) THRHR 351, 355 for the full description of this report: 'Working Group on the Treatment of Insolvency of Natural Persons Report on the treatment of the insolvency of natural persons (Insolvency and Creditor/Debtor Regimes Task Force, World Bank 2012)'. For examples of courtcentred obstructions and obstructive behaviour by role-players in circumstances where aggressive pursuit of debt collection or liquidation and distribution was preferred over collective restructuring of debt, see inter alia National Credit Regulator Debt Review Task Team Covering Report May 2010, available at <http://www. ncr.org.za/publications/circula_sep/11/NGR $\% 20 \mathrm{TT} \%$ 20 Main $\% 20$ Report $\% 20$ Final $\% 20-\% 2031 \% 20$ May $\% 202010$.pdf $>$ (site last accessed 23 July 2014) paragraph 4.1.3.2; Helena Wasserman, 'FNB plays hardball over debt review' <http://www.fin24.com/ Money/Money-Clinic/FNB-plays-hardball-over-debtreview-20100811> (Fin 24, 11 August 2010, site last accessed 23 February 2014). In respect of the repealed judicial management process, Kloppers (n 3 ) indicated at 425 that the deep rooted dependence on court intervention was too costly for small companies and at 426 that the reduction in legal costs would be notable where a process can be initiated without involving the courts.

54. See Loubser 'Defining the unincorporated business' (n 1) 444.

55. Nemaenzhe (n 3) chapter 1 pages 5-6.

56. Burdette 'Part 1' (n 53) 241, 262.

57. Idem at 254, 257 and 258. See also McCormack (n 32) 299, 299-300 and commentary at 330 as well as Henning and Pretorius (n 2) page 10-3 in the context of business rescue in South Africa.

58. Burdette 'Part 1' (n 53) 241, 243-244. 
trading further based on the information provided in respect of pre-rescue demeanour. ${ }^{59}$ Deficient entrepreneurial skills can result in a non-viable business, which may be an indication of a nationwide need for 'entrepreneurial mentors ${ }^{60}$ but which may not be a feasible option at an advanced stage of business failure where the enterprise is no longer salvageable. ${ }^{61}$

\section{(2) Conceptualising of the notion 'small and medium-sized enterprise'}

The classification of small and medium-sized businesses is no easy task ${ }^{62}$ and may differ according to the purpose of the exercise. ${ }^{63}$ A comprehensive delineation of the concept 'small business' is necessary prior to any consideration of special rescue and insolvency rules for small, micro and medium enterprises, specifically in order to determine which businesses would qualify for special treatment in respect of insolvency. ${ }^{64}$

It is therefore important to ascertain the decisive factors with respect to differentiation, if any, between different enterprises or types of entrepreneurs. The discussion hereafter deals with some important aspects to consider in respect of conceptualisation and further to put some of the terms and approaches of the South African debt relief regime referred to hereafter into perspective.

Various instruments, expanded on hereafter, exist that indicate which enterprises would fall into this given category. ${ }^{65}$ However, on multiple occasions where legislation defines small enterprises, the legislation has a specific purpose to achieve and the definition supports the scope of the projected application of the statute. ${ }^{66}$

59. Rajak and Henning (n 9) 262, 279. See also Anneli Loubser, 'Business rescue in South Africa: a procedure in search of a home?' 2007 (XL) CILSA 152, 156-157, where the author notes that the success of a specific procedure can be impacted by the perspectives that a particular judicial community (such as the courts) entertain in respect thereof. The author's comments are directed at the judicial management process, of which some perspectives at 156-157 are relevant to this discussion: The first perspective was that 'a business that was in trouble, probably did not deserve to survive anyway', the second reflected in the manner that courts applied the legislation to reduce potential misuse of the process and the third that the 'creditor-friendly insolvency system' preferred creditor payment where the creditor contested the application for judicial management.

60. Nemaenzhe (n 3) chapter 6 page 222. See e.g. Henning and Pretorius (n 2) pages $1-7$ and $1-9$, in the context of close corporations, referring to a business as 'small' based on the 'number of members' and not 'the size and scope of the operations of the corporation'. 61. See also the comments of Terdpaopong and Farooque (n 19) 119, 122 in respect of the organisations that aid businesses with extra-judicial re-arrangements in Thailand.

62. Mmakola (n 4) 66, 80; Loubser 'Defining the unincorporated business' (n 1) 444, 444. See also Terdpaopong and Farooque (n 19) 119, 120-121 for a summary of some jurisdictions' classification schemes.

63. Loubser 'Defining the unincorporated business' (n 1) 444, 444; McCormack (n 32) 299, 309 and 315-317.
64. Rajak and Henning (n 9) 262, 263-264. The authors identified seven aspects that 'modern' systems incorporate into their systems, and the first reflects on the nature of the failing debtor-business as differentiating factor for entrance into a specific rescue regime. See also McCormack (n 32) 299, 315. The author, at 317, points out that the formulation of a widespread definition in this respect is likely to be unproductive as the definition is bound to the territory in which it is proposed to function and related developments therein.

65. The distinction made by Rajak and Henning (n 9) 262, 270 and 273 in respect of 'business' and 'consumer' debtors are assumed in this article without expansion for demarcation purposes. The suggestions set out herein presume that the debts were incurred within the context of ordinary business cycles and not in the context of private consumer-consumption activities. We have only referred to selected examples, and the discussion is by no means exhaustive as other definitions of 'small business' exist - see e.g. SF du Toit, 'Reflections on the South African Code of Banking Practice' 2014 (3) TSAR 568, 568.

66. See e.g. McCormack (n 32) 299, 315-316; UNCITRAL Forty-sixth session (n 30) pages 16-17 (see also some basic commentary on a definition on page 5) in respect of the aims and outcomes of some regimes. See also some preliminary commentary on 'which debtors' in respect of the draft Guide by Anneli Loubser, 'Aiding the development of a new insolvency law in South Africa: the UNCITRAL draft Legislative Guide on Insolvency Law,' 2003 (15) SAMercL7 396, 399-400. 
It can therefore be noted that the definition of a small enterprise will constantly be amendable based on the outcomes of the legislation, which purports to define the same. ${ }^{67}$ In the premises, where insolvency rules are brought within the scope of the legislative framework, a suitable definition will have to be conceptualised. Our submission would be to use a concept that reflects the purpose for which the special rules is developed in order to allow for the necessary flexibility in practice. ${ }^{68}$

Although existing South African documents are of primary importance, it will be shown below that the features utilised for demarcation purposes are not of comprehensive assistance when drafting insolvency-related solutions for failing businesses - perhaps as insolvency is not relevant in the context of these statutes. Some straightforward examples include the type, nature and number of creditors for a specific enterprise $^{69}$ or whether the enterprise is classified as a juristic or non-juristic person. ${ }^{70}$ Whether the differentiating variables are pecuniary thresholds, employee numbers, formalisation or sector based, small businesses are undeniably diverse ${ }^{71}$ :

Small businesses can be classified as micro, very small, small or medium enterprises (SMMEs), following a complex set of thresholds per industry, as scheduled in the National Small Business Act. SMMEs are not restricted to formally registered enterprises (such as close corporations, private companies and co-operative enterprises) but include informal and non-VAT registered enterprises, such as survivalist street trading enterprises, backyard manufacturing and services, and occasional home-based evening jobs. ${ }^{72}$

We therefore note and discuss only a few variable characteristics in respect of small businesses. The first consideration is the legal status of the commercial entity, which is focal point for some jurisdictions, including South Africa, when it comes to insolvency proceedings. ${ }^{73}$ The categorisation may vary according to whether the entity is classified as a natural or juristic person with the corresponding rights, obligations and

\section{Ibid.}

68. With regard to the use of definitions and the application of same in practice/by courts, see the opinion of David Brimer and Alan Brimer 'The devil is in the definition - definitions and their limited use in legal problem solving' 2011 (14) PELF 173. See also the comment of McCormack (n 32) 299, 317: 'One may conclude on this point that it is probably not a fruitful exercise to attempt to frame a suitable definition of "small business" in any universal insolvency sense. The worth of the definition depends very much on what has preceded it in a particular jurisdiction'.

69. See e.g. Morrison (n 32) 255, 257-258.

70. See Loubser 'Defining the unincorporated business' (n 1) 444, 444; Morrison (n 32) 255, 258-259.

71. See paragraph 3.1.4 infra for references to the thresholds/factors taken into account by some South African statutes. In contrast, the position under the United States' amended Bankruptcy Code, in effect, the inserted provisions aimed at facilitating access and progress through chapter 11 proceedings, classify the 'small business' according to a debt threshold over and above the requirement of 'commercial or business activities' - see McCormack (n 32) 299, 311 and also Lijie Qi, 'The rise of pre-packaged corporate rescue on both sides of the Atlantic' 2007 20(9) Insolvency Intelligence 129, 130. See also Lois Lupica, 'Insol International Small Practices and Consumer Debt Issues USA November 2013' 2013 for general information regarding chapters 7, 11 and 13 of the United States Bankruptcy Code. Gary Cook and Keith Pond, 'Explaining the choice between alternative insolvency regimes for troubled companies in the UK and Sweden' 2006 22(1) European Fournal of Law and Economics 21, 21-22 et seq illustrate the position with regard to the adoption of processes similar to Chapter 11 in jurisdictions such as the UK and Sweden. See Loubser 'Defining the unincorporated business' (n 1) 444, 449-451 for a discussion of chapter 11 proceedings.

72. The Department of Trade and Industry, Annual Review of Small Business in South Africa 2005-2007 August 2008, available at <http://www.dti.gov.za/ sme development/docs/3\%20Annual $\% 20$ Review $\% 20$ Final $\% 20$ Report $\% 2011 \% 20 A u g \% 2008 . p d f>$ (site last accessed 23 July 2014) page xxiii.

73. See paragraph 3.1.4 infra. See contra the approach of the EC Recommendation (n 36) page 5 paragraph II 5(a) where both 'natural' and 'legal person' is included in the definition of 'debtor' - the discerning factor is that insolvency is a probability. 
risk-bearing estate or whether the focus is on the business/economic activity of the entity - such as whether the entity is a consumer in the traditional consumption-related sense of the word or a trader/entrepreneur. ${ }^{74}$ In line with the comments of Mmakola, we concur that, within the context of this discussion and later considerations of liquidation and reorganisation, the mind-set or business objective of the entrepreneur is of utmost importance. ${ }^{75}$ Secondly, a distinction seems necessary between different types of entities, ${ }^{76}$ as the 'one-size fits all' approach in respect of all types of businesses did not seem to be a viable option for many systems. ${ }^{77}$

Neither the objectives of the business owner nor the concepts of 'juristic person' or 'natural person' account for two characteristic of the small business, which are the intricate manner in which the business owner is linked to the business itself ${ }^{78}$ and the size of the business-debtor. ${ }^{79}$ Whilst legislation may dictate behaviour expected from company directors, for example, which may lead to considerations of accountability of directors, many natural person 'owners' are inevitably accountable through invested personal assets in the business ${ }^{80}$ even though it may be a juristic person.

74. Loubser 'Defining the unincorporated business' (n 1) 444, 444; Kloppers (n 3) 417, 418. See also UNCITRAL Forty-sixth session (n 30) page 16: 'An insolvency system covering MSMEs should combine these characteristics: it should aim to maximize assets and preserve the company on one hand and provide for discharge and a fresh start for the entrepreneurs involved on the other. The goal would be to distinguish the effects of insolvency on the enterprise from those on the individuals behind the enterprise. Continuity is possible for an incorporated entity, but more difficult for an individual operating without the protection of incorporation'.

75. Paragraph 3.1.1 supra. See the comments of Burdette 'Part 1' (n 53) 241, 258 referring to the UNCITRAL Guide: '[ [] n circumstances where technical expertise and goodwill are more important than physical assets, the preservation of human resources and business relations are essential elements of value that cannot be realised through liquidation'.

76. Loubser 'Defining the unincorporated businesses' (n 20) 444, 445-446 indicates with reference to the UNCITRAL Guide that this should be a country-specific decision based on the characteristics of the entities of that country.

77. See Loubser 'Defining the unincorporated businesses' (n 20) 444, 460; McCormack (n 32) 299 specifically at 309-310. However, see also the comments of Rajak and Henning (n 9) 262, 273 in respect of business rescue despite the nature of the legal nature of the debtor, focusing on the concept of 'business'. 78. Morrison (n 32) 255, 256.

79. See e.g. McCormack (n 32) 299, 309 - see also the comment at 314 that '[i]n essence, a small business may not survive the cure for its financial ills'. McCormack argues at 309 that the restructuring process set out in Chapter 11 of the USA Bankruptcy Code, pertaining to both large and small businesses, is 'simply too intricate, convulated and expensive for small businesses'. At 315 he notes that a motivation for distinguishing between businesses of different sizes is whether the cost versus return ratio is beneficial in respect of the procedure implemented in attempts at restructuring. A further consideration stated by the author at 315 is whether there is a complicated business structure with multiple 'layers of debt' involved. The author also refers to the National Bankruptcy Review Commission Report (see e.g. 310) and indicates that the report indicated that the liabilities of the debtor could be a core indicator of the relevance of a particular process, in the discussed circumstances Chapter 11.

80. Mann (n 1) 1, 10 and 19; see further Rajak and Henning (n 9) 262, 270-271 and Loubser 'Defining the unincorporated business' (n 1) 444, 444 in respect of the latter author's comment that the rationale for differentiation in both categorisation and the resultant treatment of debtors is the 'substantial difference in the priorities applicable to the insolvency of the respective groups'. The author further continues at 445 to distinguish between the consideration of stakeholders when the impact of insolvency is considered (such as dependants and creditors) and then ultimately refers to the crux of the matter through reference to the UNCITRAL Legislative Guide. The 'blurring of the lines' between the business owner as a natural person is aptly noted when Loubser states at 445 that 'although the interests of natural persons involved in business are different from those of consumer debtors, it is often difficult to separate the personal liabilities of a debtor from his business debts. . . as a result of the fact that a sole proprietorship is not recognized as a separate legal entity, the owner is in any case personally liable for all the business's debts'. Of further importance is the author's statement at 447 in respect of the restraints caused by the insolvent status of a businessman prior to rehabilitation and notwithstanding that a composition may have been entered into with creditors: 'Having his property restored but not his legal capacity, will make it very difficult, if not impossible, for the owner of an unincorporated business to resume trading'. References omitted. 
The potential loss due to the restriction on enforcement against the natural person owner where the financial assistance was rendered to a failed juristic person induces lenders to provide financial assistance to the owner personally or to require surety from the owner in the form of his or her personal assets. ${ }^{81}$

(i) Legal personality: Natural and recognised juristic persons have legal personality and require contractual capacity consistent with the prescriptions of the applicable legal regime in order to participate in the commercial world in a legally recognised manner. ${ }^{82}$ Small businesses are often intricately linked with the owner ${ }^{83}$ and main trader as aptly illustrated where the business is a so-called 'one-man business'. ${ }^{84}$ Internationally, this link has not gone unnoticed:

One issue that may need to be taken into account in considering discharge of natural persons engaged in a business undertaking is the intersection of business indebtedness with consumer indebtedness. Recognizing that different approaches are taken to the insolvency of natural persons (in some States a natural person cannot be declared bankrupt at all, while in others there is a requirement for the person to have acted in the capacity of a 'merchant') and that many States do not have a developed consumer insolvency system, a number of States have insolvency laws that seek to distinguish between those who are simply consumer debtors and those whose liabilities arise from small businesses. Since consumer credit is often used to finance small business either as start-up capital or for operating funds, it may not always be possible to separate the debts into clear categories. For that reason, where a legal system recognizes both consumer and business debt, it may not be feasible to have rules on the business debts of natural persons that differ from the rules applicable to consumer debts. ${ }^{85}$

In this regard, the business essence of the owner and main trader is inseparable from that of the enterprise. ${ }^{86}$ Partnerships and non-juristic person associations are also linked in a direct manner to the natural persons who conduct the business in an owner/manager fashion although, depending on whether the common law or specific legislation is applicable, may or may not qualify as 'juristic' persons under certain circumstances. ${ }^{87}$ In respect of liabilities for debts, a liquidated juristic person,

81. Feasibility (Pty) Ltd, Report to the National Credit Regulator The cost of credit, access to credit and associated market practices August 2011 <http://www.ncr.org.za/ press_release $/ 2011 \% 2008 \% 20$ Access $\% 20$ to $\% 20$ credit $\%$ 20Feasibility\%20report.pdf $>$ accessed 20 January 2014 pages 194-195. See also 'More ways to secure working capital' < http://www.fin24.com/Entrepreneurs/Getting-Started/More-ways-to-secure-working-capital-2014 0624> (Fin 24, 24 June 2014, site last accessed 2 July 2014). For a general perspective on surety and views on the exclusion of natural persons from the ambit of the protection of the National Credit Act 34 of 2005 under certain circumstances, see Michelle Kelly-Louw, 'Should all natural persons standing surety have the protection of the National Credit Act 34 of 2005?' 2012 (24) SAMercL7 298. See also Ingrid Goodspeed 'The Credit Market' in Karin van Wyk et al. (ed) Understanding South African financial markets $4^{\text {th }}$ edn, Van Schaik Publishers 2012 page 498: 'A small and medium enterprise (SME) is a firm that has only a small share of its market and is managed by its owner(s). SMEs are not large enough to access the stock exchange to raise capital. Since they have little recourse to institutional sources of finance other than banks, they tend to rely heavily on the personal savings of proprietors, family and friends'.

82. Chris Nagel (ed), Commercial Law $4^{\text {th }}$ edn LexisNexis 2011 pages $75 \& 87$.

83. Morrison (n 32) 255, 256; Schoeman (n 40) pages 97-98.

84. Nagel (n 82) page 87. See also Schoeman (n 40) pages $97-98$.

85. UNCITRAL Legislative Guide (n 32) page 284.

86. See Schoeman (n 40) pages 97-98.

87. See Nagel (n 82) pages 87-88; sections 1 of the Companies Act 71 of 2008, Consumer Protection Act 68 of 2008 and National Credit Act 34 of 2005. 
as and where the legislative regime provides for it, dissipates after completion of proceedings and unpaid debts are ordinarily distinguished. ${ }^{88}$ Debts of businesses that are categorised as 'natural persons' may, as a result of the link with the owner indicated above, subsist as a liability of the human being even though the business has ceased to continue. ${ }^{89}$ Partnerships under South African law are cases in point. Some statutes classify 'partnerships' as juristic persons although this was not the position at South African common law. ${ }^{90}$ Two notable aspects with regard to partnerships are that the individual partners are jointly and severally liable for the remaining debts of the partnership after same has been disbanded, ${ }^{91}$ and, where the partnership estate is sequestrated, section 13(1) of the Insolvency Act 24 of 1936 mandates that all personal estates of the partners be sequestrated at the same time.

However, a small business may under certain circumstances also comply with the requirements of legal personality as a juristic person, whether as a company (including a co-operative for purposes of this discussion) or close corporation. ${ }^{92}$ At present, there are two forms of juristic persons recognised by South African law that requires positive action from the owner and main trader in the form of inter alia compliance with registration requirements to realise. ${ }^{93}$ Legislation has expanded the concept of 'juristic person' for purposes of the Companies Act 71 of 2008, the Consumer Protection Act 68 of 2008 and the National Credit Act 34 of 2005. ${ }^{94}$ Successful registration and continuous compliance with legislative provisions will allow the juristic person to acquire and maintain an estate with recognisable rights and obligations separate from that of the natural person that created the entity or derives benefits from the business activities of the enterprise. ${ }^{95}$

(ii) The enterprise: The concept 'small enterprise' in its varying forms has been defined in different South African statutes. The most apparent is the definition set out in the National Small Businesses Act, ${ }^{96}$ which other statutes such as the National Credit Act 34 of 2005 incorporate through direct reference in its definitions chapter. ${ }^{97}$ The

88. Morrison (n 32) 255, 259.

89. Idem - unless the person has been subjected to a process that allows for a discharge such as the sequestration process in terms of the South African Insolvency Act. 90. Nagel (n 82) pages 87-88.

91. Idem at page 113 .

92. Henning and Pretorius (n 2) page 1-3; Beuthin and Luiz (n 6) chapter 33 pages 303 and 304.

93. See e.g. Chapter 2 Part B of the Companies Act 71 of 2008; Parts 1 and 3 of the Close Corporations Act 69 of 1984.

94. Herein respectively referred to as the '2008 CA', 'NCA' and 'CPA'.

95. Nagel (n 82) pages 87-88; see e.g. Chapter 2 Part $\mathrm{G}$ (specifically section 82 in respect of failure to comply with administrative duties such as filing annual returns) of the $2008 \mathrm{CA}$.

96. Act 102 of 1996, as amended by the National Small Business Amendment Acts 26 of 2003 and
29 of 2004. Hereinafter the 'NSBA'. However, see the comments by Feasibility (Pty) Ltd (n 81) page 194 in respect of the lack of correspondence between the provided definitions in the NSBA and the criteria applied by credit providers. Interestingly, the author juxtaposes the definitions set out in the NSBA with the 'needs of credit providers', stating that the former does not 'conform' to the latter instead of vice versa and is therefore 'not consistently applied'.

97. Two other examples referring to the criteria of the NSBA (now the National Small Enterprises Act after amendment by section 10 of the National Small Business Amendment Act 29 of 2004) in their definitions sections are the Competition Act 89 of 1998 and the Media Development and Diversity Agency Act 14 of 2002. The NCA mistakenly refers to the 'Small Businesses Act', which should actually be a referral to the 'National Small Enterprises Act'. 
definition in section 1 of the National Small Business Act determines that a 'small business' is interpreted to

[mean] a separate and distinct business entity, including cooperative enterprises and non-governmental organisations, managed by one owner or more which, including its branches or subsidiaries, if any, is predominantly carried on in any sector or subsector of the economy mentioned in column I of the Schedule and which can be classified as a micro-, a very small, a small or a medium enterprise by satisfying the criteria mentioned in columns 3, 4 and 5 of the Schedule opposite the smallest relevant size or class as mentioned in column 2 of the Schedule.

There are three categorisation criteria in columns three to five of the schedule that are in relation to two substantive markers set out in columns one and two. The substantive markers are sector and size specific, in effect, the '[s]ector or subsector in accordance with the Standard Industrial Classification' and the '[s]ize of the class'. The sectors are respectively identified as Agriculture; Mining and Quarrying; Manufacturing; Electricity, Gas and Water; Construction; Retail and Motor Trade and Repair Services; Wholesale Trade, Commercial Agents and Allied Services; Catering, Accommodation and Other Trade; Transport, Storage and Communications; Finance and Business Services; Community, Social and Personal Services. ${ }^{98}$ The '[s]ize of [the] class' refers to whether the business will be classified as a medium, small, very small or micro business if the business conforms to the categorisation criteria. The first criteria is ' $\mathrm{t}] \mathrm{he}$ total full-time equivalent of paid employees', the second is the ' $[\mathrm{t}]$ otal turn-over' and the third is the ' $[\mathrm{t}]$ otal gross asset value', the latter that does not include fixed property.

In general and from an employee-equivalent perspective, a medium enterprise generally has 200 full-time employees, a small enterprise 50 employees, very small enterprises 20 and micro enterprises 5 employees. ${ }^{99}$ The deviation from the general rule is found in the Agriculture Sector, where a medium enterprise has 100 full-time equivalent employee positions, a small enterprise 50 positions, very small enterprises 10 and a micro enterprise 5 full-time paid employee positions. ${ }^{100}$

In terms of the National Credit Act, a juristic person is defined as 'include[ing] a partnership, association or other body of persons, corporate or unincorporated, or a trust if there are three or more individual trustees; or the trustee is itself a juristic person, but does not include a stokvel'. In terms of the Companies Act of 2008, the concept of a juristic person for purposes of that Act is defined as 'a foreign company; and a trust, irrespective of whether or not it was established within or outside the Republic'. ${ }^{101}$ The Companies Act of 2008 does not define enterprises to which it applies according to size or worth as a point of departure. However, size does become relevant when the business rescue practitioner stands to be appointed for purposes of chapter 6 proceedings as the level of experience of the practitioner dictates whether that practitioner is eligible to be appointed for a small, medium or large company. ${ }^{102}$

98. Schedule 1 Column 1 of the NSBA.

99. Schedule 1 Column 3 of the NSBA.

100. Ibid.

101. Hypothetically, the scope of these definitions, for purposes of a trust with less than three trustees and which is not a juristic person itself, may render both debt review (as a form of debt relief under the auspices of the NCA) and business rescue (under the $2008 \mathrm{CA}$ ) viable options.

102. Regulation 127. 
Regulation 127 of the Companies Regulations 2011 to the Companies Act 71 of 2008 is one of the limited non-small business-specific statutes that differentiate between the sizes of the company. In this regard, the distinction is made for the purposes of precluding the appointment of a business rescue practitioner of a particular level of experience to a company of a certain size. ${ }^{103}$ The distinguishing criterion is the 'most recent public interest score' indicated in accordance with regulation 26(2). ${ }^{104}$ '[L]arge' companies' scores equal or exceed 500, ${ }^{105}$ 'medium' companies' scores include 'public' companies with scores lower than 500 or, where another company is applicable, a score equal or more than 100 but not equal to or exceeding $500^{106}$ and 'small' companies' scores are smaller than $100 .{ }^{107}$ Regulation 26(2) also applies to regulations other than regulation 127 and sets out the 'public interest score' that has to be determined by 'every company ... at the end of each financial year'. The score is established with reference to the following factors pertaining to the financial year to which it applies: The quantity of employees, 'third party liability', financial revenue and persons who enjoy a 'beneficial interest in any of the company's issued securities' or are a 'member ... or a member of an association that is a member of the company', depending on whether the company is a 'profit' or 'non-profit' company. ${ }^{108}$

In the context of business rescue proceedings, the relevant experience of the business rescue practitioner is relatable to the score-indicated size of the company, with the least experienced practitioner being eligible to conduct proceedings for a small company and the more experienced practitioner being eligible to conduct proceedings for larger companies. ${ }^{109}$

\footnotetext{
103. Specifically regulation $127(2)($ b) and (c). For commentary on business rescue practitioners under the auspices of chapter 6 of the Companies Act 71 of 2008, see e.g. Lézelle Jacobs, 'Ondersoek na die bevoegdhede en aanspreeklikheid van die ondernemingsreddingspraktisyn as maatskappydokter' 2013 10(1) Lit Net Akademies 54; note 118 infra.

104. Regulation 127 (b).
}

105. Regulation 127 (b)(i).

106. Regulation 127 (b)(ii) (aa) and (bb) respectively. 107. Regulation 127 (b)(iii). 108. Regulation 127 (2) (a)-(d).

109. Regulation 127. See Chiwete (n 8) chapter 3 page 21 - the author is of the view that a small company should also be favoured with an additionally skilled and knowledgeable practitioner. 